\title{
Retinoblastoma Clinical Distant Metastasis TNM Finding v7
}

National Cancer Institute

\section{Source}

National Cancer Institute. Retinoblastoma Clinical Distant Metastasis TNM Finding v7.

NCI Thesaurus. Code C88775.

A clinical finding about one or more characteristics of retinoblastoma, following the rules of the TNM AJCC V7 classification system as they pertain to distant metastases. 